\title{
Pengaruh Harga Terhadap Volume Penjualan Pada Mebel Sinar Barokah Tanjung Karangan Kabupaten Muara Enim
}

\author{
Agusri \\ STIE Serasan Muara Enim, agusri123@gmail.com
}

\begin{abstract}
ABSTRAK
Penelitian ini bertujuan untuk mengetahui seberapa besar pengaruh harga terhadap volume penjualan Mebel Sinar Barokah Tanjung Karangan Kabupaten Muara Enim. Data yang digunakan adalah data primer dan penyebaran kuesioner kepada 23 responden. Model analisa yang digunakan analisis regresi liner sederhana. Uji karakteristik data yaitu uji Realibilitas, uji validitas dan uji korelasi ,dimana hasil pengujian regresi linier sederhana menunjukkan bahwa harga berpengaruh positif terhadap volume penjualan mebel Sinar Barokah Tanjung Karangan
\end{abstract}

Kata Kunci : Pengaruh Harga dan Volume Penjualan

\section{A. PENDAHULUAN}

Perkembangan dunia usaha saat ini berjalan dengan pesat, yang secara tidak langsung menciptakan suatu persaingan, hal ini menuntut pelaku ekonomi untuk lebih peka, kritis dan reaktif terhadap perubahan yang ada, baik perubahan secara mikro maupun global. Langkah yang bisa ditempuh oleh pelaku ekonomi adalah bisa menciptakan dan mempertahankan konsumen /pelanggan. Agar tujuan tersebut tercapai, maka setiap perusahaan harus berupaya menghasilkan dan menjual barang dan jasa yang diinginkan konsumen dengan harga yang bersaing.

Pemasaran merupakan suatu system keseluruhan dari kegiatan bisnis yang ditujukan untuk merencanakan, menentukan harga serta mempromosikan barang dan jasa terhadap pemuasan kebutuhan baik kepada pembeli yang ada maupun kepada pembeli potensial. dan perusahaan harus melakukan berbagai strategi pemasaran sesuai dengan jenis produk yang dipasarkan, apakah berupa barang atau jasa karena strategi pemasaran merupakan pokok yang akan digunakan oleh unit bisnis dalam mencapai suatu sasaran yang telah ditetapkan terlebih dahulu. Industri mebel merupakan salah satu sektor industri yang terus berkembang dimana kebutuhan akan produk-produk dari industri mebel terus meningkat karena sektor ini memberikan prospek yang cendrung meningkat, desain dan bentuknya beragam serta nilai artistik yang dapat memberikan kenyamanan dan nilai seni yang tinggi.

Harga merupakan suatu nilai tukar yang bisa disamakan dengan uang atau barang lain untuk manfaat yang diperoleh dari suatu barang atau jasa bagi seseorang atau kelompok pada waktu tertentu dan tempat tertentu. Penentapan harga sebenarnya cukup sulit karena penetapan harga ini memerlukan suatu pendekatan yang sistimatis ,yang melibatkan penetapan tujuan dan perkembangan harga itu sendiri.Menurut Philif Kotler (2008:519) mengatakan bahwa harga adalah satusatunya elemen bauran pemasaran yang menghasilkan pendapatan, elemen lainnya menimbulkan biaya. Harini (2008:121) harga merupakan nilai uang yang seseorang butuhkan 
untuk memperoleh sejumlah produk dan pelayanan

Pada umumnya tingkat harga yang lebih rendah biasanya memicu jumlah produk yang diminta akan tinggi Dalam ilmu ekonomi harga dapat dikaitkan dengan nilai jual atau beli suatu produk barang atau jasa sekaligus sebagai variabel yang menentukan komparasi produk atau barang sejenis, sebab dalam kehidupan sehari-hari konsumen tidak dapat terlepas dari pengaruh harga dan harga dikatakan mahal, murah atau biasa-biasa saja dari setiap individu tidak harus sama, karena tergantung dari persepsi individu yang dilatar belakangi oleh lingkungan kehidupan dan kondisi individu (Schifman dan Kanuk, 2001:138).

Menurut Stanton (2004:308) ada empat indikator di dalam harga yaitu, keterjangkauan harga, kesesuaian harga dengan kualitas produk, daya saing harga, dan kesesuaian harga dengan manfaat produk. Pada umumnya konsumen akan lebih tertarik pada produk dengan harga yang lebih murah, apalagi kualitas produk yang dihasilkan dengan yang lain tidak jauh berbeda. Oleh karena itu penetapan harga yang tepat dapat meningkatkan keputusan pembelian, dan memaksimalkan volume penjualan bagi perusahaan terkait.

Dalam menetapkan harga, produsen dapat menetapkan dengan beberapa alternatif seperti sebagai berikut (Zeithaml \& Bitner, 1996) : Penetapan harga berdasarkan biaya (cost-based pricing), Penetapan harga berdasarkan harga competitor, Pendekatan harga berdasarkan permintaan (demand-based pricing).

Volume penjualan merupakan hasil akhir yang dicapai perusahaan dari penjualan produk yang dilakukan oleh salesman dan tenaga penjual lainnya. Volume penjualan dihitung berdasarkan target yang diasumsikan dengan realisasi yang dicapai. Volume penjualan tidak memisahkan secara tunai msupun kredit, tetapi dihitung secara keseluruhan dari total yang dicapai. Maka kalau volume penjualan meningkat dan biaya distribusi menurun maka tingkat pencapaian laba perusahaan meningkat. Tetapi sebaliknya bila volume penjualan menurun maka pencapain laba perusahaan menurun.

Menurut Schiffan (2005: 118), volume penjualan adalah tingkat penjualan yang diperoleh perusahaan untuk priode tertentu dalam satuan (unit/total/rupiah). Sedangkan menurut Efendi Pakpahan (2009) faktor yang sangat penting dalam mempengaruhi volume penjualan adalah saluran distribusi yang bertujuan untuk melihat peluang pasar apakah dapat memberikan laba yang maksimal. Secara umum saluran distibusi yang semakin luas akan menimbulkan biaya yang lebih besar, tetapi semakin luasnya saluran distribusi maka produk perusahaan akan semakin dikenal oleh masyarakat luas dan mendorong naiknya angka penjualan yang akhirnya berdampak pada peningkatan volume penjualan.

Penetapan harga jual produk selain mengacu pada jenis dan desain pihak Usaha Mebel Sinar Barokah juga menerapkan tambahan biaya pengiriman yang dimasukan ke harga penjualan suatu produk, sehingga secara tidak langsung konsumen menilai harga yang ditawarkan Usaha Mebel Sinar Barokah terlihat tinggi dibandingkan harga yang ditawarkan dari usaha mebel yang lain. Harga yang ditawarkan oleh Usaha Mebel sinar barokah sekarang ini berpariatif disesuaikan dengan jenis produk dan desain yang diminta oleh konsumen.

Dalam proses usahanya, Usaha Mebel Sinar Barokah menetapkan 
harga yang di sesuaikan dengan kualitas produknya agar target penjualan yang telah ditetapkan dapat tercapai dan terus meningkat. Target penjualan yang telah ditetapkan Mebel sinar Barokah selama 3 tahun terakhir mengalami Fluktuasi penjualan. Meskipun prosedur produksi dan pemasaran telah dilakukan dengan baik, pada kenyataannya Volume penjualan pada Mebel Sinar Barokah masih mengalami penurunan. Berikut penulis sajikan tabel data penjualan Mebel Sinar Barokah Tanjung Karangan.

Tabel 1

Data Penjualan Usaha Mebel Sinar Barokah Tahun 2015-2017

\begin{tabular}{|c|c|c|c|c|c|}
\hline No & Nama Barang & Target & $\begin{array}{c}\text { Tahun } \\
\mathbf{2 0 1 5}\end{array}$ & $\begin{array}{c}\text { Tahun } \\
\mathbf{2 0 1 6}\end{array}$ & $\begin{array}{c}\text { Tahun } \\
\mathbf{2 0 1 7}\end{array}$ \\
\hline 1 & Lemari 3 Pintu & 45 unit & 43 unit & 52 unit & 48 unit \\
\hline 2 & Lemari 2 pintu & 54 unit & 58 unit & 56 unit & 51 unit \\
\hline 3 & Kursi Tamu & 60 unit & 64 unit & 62 unit & 56 unit \\
\hline 4 & Kursi Makan & 55 unit & 60 unit & 50 unit & 47 unit \\
\hline \multicolumn{2}{r|}{ Total Penjualan } & $\mathbf{2 1 4}$ unit & $\mathbf{2 2 5}$ unit & $\mathbf{2 2 0}$ unit & $\mathbf{2 0 2}$ unit \\
\hline
\end{tabular}

Sumber : Usaha Mebel Sinar Barokah, 2017

Dari tabel 1 Pada Mebel Sinar Barokah dapat dilihat penjualan pada setiap tahunnya Mengalami fluktuasi. pada produk lemari 3 pintu penjualan pada tahun 2015 penjualan menurun sebesar 43 unit dari target 45 unit dengan persentase $(0,96 \%)$ sementara harga yang ditetapkan tidak mengalmi kenaikan, pada tahun 2016 mengalami kenaikan penjualan dari target 45 unit terjual 52 unit dengan persentase kenaikan 1,16\%, dan pada tahun 2017 kembali mengalami penurunan dari tahun 2015. Pada Produk Lemari 2 pintu penjualan pada tahun 2015 sebesar 58 unit dari target 54 unit dengan persentase $(1,07 \%)$ mengingat harga jauh lebih murah dengan lemari 3 pintu. Pada Produk kursi tamu penjualan pada tahun 2015 penjualan dari target 60 unit terjual 64 unit dengan persentase $(1,067 \%)$, tahun 2016 penjualan mengalami penurunan dari tahun sebelumnyat dengan persentase $\quad 1,033 \% \quad$ adanya kecendrungan perubahan model, dan tahun 2016 penjualan target 60 unit hanya terjual sebesar 56 unit dengan persentase penurunan $0,93 \%$. Produk Kursi Makan penjualan pada tahun 2015 penjualan sebesar 60 unit dari target 55 unit dengan persentase $1,09 \%$,

Berdasarkan hasil penelitian awal yang dilakukan penulis yang turunnya volume penjualan selain harga yang ditawarkan juga biaya pengiriman produk setengah jadi mengalami kenaikan karena kenaikan harga BBM dan kegiatan promosi masih bersifat menunggu pembeli datang. Berdasarkan uraian diatas, maka dalam penelitian ini penulis tertarik untuk mengambil judul "pengaruh harga terhadap volume penjualan pada usaha mebel 


\section{B. KAJIAN TEORI}

1). Pengertian Harga

Harga merupakan salah satu penentu keberhasilan suatu perusahaan karena harga menentukan seberapa besar keuntungan yang akan diperoleh perusahaan dari penjualan produknya baik berupa barang maupun jasa.Menetapkan harga terlalu tinggi akan menyebabkan penjualan akan menurun, namun jika harga terlalu rendah akan mengurangi keuntungan yang dapat diperoleh organisasi perusahaan.

Menurut Tjiptono 2002 harga adalah hukurn moneter yang dapat ditukarkan untuk mendapatkan hak atas suatu barang atau pemakaian layanan jasa.Berdasarkan pengertian harga menurut para ahli diatas dapat disimpulkan bahwa harga adalah nilai uang yang ditentukan secara global yang harus dikeluarkan oleh seseorang untuk mendapatkan suatu produk atau pelayanan jasa yang diinginkan.

2). Strategi penetapan Harga

Beberapa strategi harga dalam marketing antara lain sebagai berikut :

a. Market Skimming

1. Penetration princing

Penentuan harga produk baru yang relatife murah dengan tujuan memperluas pangsa pasar. Pendekatan ini sesuai jika pasar bersifat elastis.

2. Prestige and Economy Princing

Prestige Princing adalah strategi yang menaikkan harga barang dan jasa diatas harga rata-rata economy princing dengan menurunkan harga barang dan jasa dibawah rata-rata.

3. Multiple Princing

Strategi ini merupakan diskon kuantitas. Harga yang lebih murah dikenakan jika kuantitas produk atau service yang dibeli semakin banyak.
3) Pengertian Volume Penjualan

Volume penjualan merupakan hasil akhir yang dicapai perusahaan dari penjualan produk yang dilakukan oleh salesman dan tenaga penjual lainnya. Volume penjualan dihitung berdasarkan target yang diasumsikan dengan realisasi yang dicapai. Volume penjualan tidak memisahkan secara tunai msupun kredit, tetapi dihitung secara keseluruhan dari total yang dicapai. Maka kalau volume penjualan meningkat dan biaya distribusi menurun maka tingkat pencapaian laba perusahaan meningkat. Tetapi sebaliknya bila volume penjualan menurun maka pencapain laba perusahaan menurun.

Philip Kotler, (2000 : 68) menyatakan volume penjualan adalah barang yang terjual dalam bentuk uang untuk jangka waktu tertentu yang didalamnya mempunyai strategi pelayanan yang baik.

Basu Swasta (2005:65) menyatakan volume Penjualan merupakan penjualan bersih dari laporan laba perusahaan. Penjualan bersih melalui hasil penjualan seluruh produk (produk lini) selama jangka waktu tertentu dan hasil penjualan yang dicapai dari market share (pangsa pasar) yang merupakan penjualan potensial yang dapat terdiri dari kelompok pembeli selama jangka waktu tertentu.Dalam kegiatan pemasaran kenaikan volume penjualan merupakan ukuran efisensi, meskipun tidak setiap kenaikan volume penjualan diikuti dengan kenaikan laba.

Menurut Basu Swasta dan irawan (2008:197) ada beberapa indikator volume penjualan yaitu sebagai berikut :

a) Kondisi dan kemampuan penjual 
Untuk mencapai sasaran penjualan yang diharapkan, maka penjual harus memahami masalah-masalah penting yang sangat berkaitan dengan penjualan yakni jenis dan karakteristik barang yang ditawarkan, harga Produk, syarat penjualan

b) Kondisi pasar

Pasar sebagai suatu kelompok pembeli atau pihak yang menjadi sasaran dalam penjualan, kondisi pasar yang harus diperhatikan adalah jenis pasarnya, kemmpuan segemen pasar, daya beli masyarakat dan keinginan dan kebutuhan.

c). Modal

Modal diperlukan untuk mengelola perusahaan dan operasional perusahaan selama perusahaan hidup.

d) Kondisi organisasi perusahaan

Dalam menangani masalahmasalah penjualan di dalam suatu perusahaan dapat dilihat dari kondisi organisasi perusahaannya, apakah termasuk jenis perusahaan besar atau kecil.

e) Faktor lain

Faktor-faktor lain yang sering mempengaruhi penjualan, seperti periklanan, peragaan, kampanye, pemberian hadiah, diskon, dam lain-lain. faktor-faktor yang mempengaruhi volume penjualan antara lain : Kualitas barang.s,elera konsumen,Servis dan persaingan menurunkan harga jual

\section{c. POPULASI DAN SAMPEL}

1). Populasi

Sugiyono (2012:115) menyatakan Populasi adalah wilayah generalisasi yang terdiri atas objek/subjek yang mempunyai kualitas dan karakteristik oleh peniliti untuk dipelajari dan kemudian dapat ditarik kesimpulan, dalam penelitian ini populasi penelitian ini adalah Populasi dalam penelitian ini adalah konsumen yang sudah melakukan pembelian di Usaha Mebel Sinar Barokah Tanjung Karangan yang berjumlah 23 orang.

2). Sampel

Sugiyono (2012:116) Sampel adalah bagian dari jumlah yang dimiliki oleh populasi, teknik pengambilan sampel pada penelitian ini adalah penelitian menggunakan teknik perhitungan dengan menggunakan Rumus Slovin, jadi sampel yang dihasilkan yaitu sebagian dari konsumen yang telah membeli produk pada usaha Mebel Sinar Barokah Tanjung Karangan yang berjumlah 23 orang.

\section{Kerangka Berfikir}

Kerangka

pemikiran

merupakan suatu modal konseptual tentang bagaimana teori berhubungan dengan berbagai factor yang telah diidentifikasikan sebagai masalah atau penelitian. Menurut Philip Kolter,(2008:345) Harga (price) adalah jumlah semua nilai yang diberikan oleh pelanggan untuk mendapatkan diberikan oleh pelanggan untuk mendapatkan keuntungan dari memiliki atau menggunakan suatu produk atau jasa.

Kerangka Penelitian

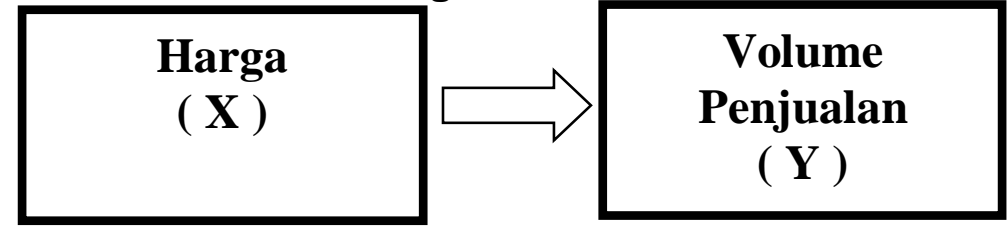




\section{HASIL PENELITIAN}

1) Pengujian Validitas Data

Validitas menunjukkan ukuranukuran yang benar mengukur apa yang akan diukur. Dalam penelitian ini uji validitas dapat dilakukan dengan metode korelasi Croncbach Alpha. Pada metode Cronbach's Alpha nilai R-hitung diwakili oleh nilai Corrected Item-Total Correlation, Nilai tersebut kemudian dibandingkan dengan $r$ tabel yang dicari pada tingkat (signifikasi 0,05 dengan uji 2 sisi) dan jumlah data sebanyak $(n)=23$ sehingga diperoleh nilai $r$ tabel sebesar 0,413. Dalam pengujian validitas data.

a) Validitas Harga

Dari out put dapat diketahui nilai korelasi antara skor item X (harga) dam skor Total $X$ (Harga). Nilai ini kita bandingkan dengan $r$ tabel, $r$ tabel dapat dicari pada taraf signifikasi 0,05 dengan uji 2 sisi dan jumlah data $(n)=23$, maka didapat $r$ tabel sebesar 0,413.

Tabel 2

Hasil Uji Validitas variabel Harga

\begin{tabular}{|c|c|c|c|c|}
\hline No & Ppertanyaan & r hitung & $\mathbf{r}$ tabel & Keterangan \\
\hline 1 & Item 1 & 0,643 & 0,413 & Valid \\
\hline 2 & Item 2 & 0,867 & 0,413 & Valid \\
\hline 3 & Item 3 & 0,643 & 0,413 & Valid \\
\hline 4 & Item 4 & 0,637 & 0,413 & Valid \\
\hline 5 & Item 5 & 0,577 & 0,413 & Valid \\
\hline
\end{tabular}

Sumber: data yang diolah dari kuesioner

b) Variabel volume penjualan

Dari output dapat diketahui nilai korelasi antara skor item $Y$ (Volume penjualan) dan skor total $Y$ (volume penjualan). Nilai ini kita bandingkan dengan $r$ tabel, $r$ tabel dapat kita cari pada taraf signifikansi 0,05 dengan uji 2 sisi dan jumlah data $(n)=23$, maka $r$ tabel sebesar 0,413 .

Tabel berikut ini menyajikan hasil uji validitas untuk masing-masing item pertanyaan variabel volume penjualan dalam kuesioner.

Tabel 3

Hasil Uji Validitas Volume Penjualan

\begin{tabular}{|c|c|c|c|c|}
\hline No & Pertanyaan & $r$ hitung & $r$ tabel & Keterangan \\
\hline 1 & Item 1 & 0,662 & 0,413 & Valid \\
\hline 2 & Item 2 & 0,729 & 0,413 & Valid \\
\hline 3 & Item 3 & 0,801 & 0,413 & Valid \\
\hline 4 & Item 4 & 0,744 & 0,413 & Valid \\
\hline 5 & Item 5 & 0,669 & 0,413 & Valid \\
\hline
\end{tabular}

Sumber: data yang diolah dari kuesioner

2) Pengujian Realibitas Data

Dalam penelitian ini uji reliabilitas dilakukan dengan metode Cronbach's Alpha. Nilai yang telah diperoleh dengan metode tersebut kemudian dibandingkan dengan koefisien berdasarkan kriteria penerimaan reliabilitas yaitu lebih besar dari 0,6.

a) Variabel Harga $(X)$

Uji reliabilitas variabel harga menggunakan SPSS versi 21 for windows yaitu dengan hasil : 
Tabel 4

Reliabilitas Statistik

\begin{tabular}{|c|c|c|}
\hline $\begin{array}{c}\text { Cronbach's } \\
\text { Alpha }\end{array}$ & N of Item & Hasil Reliabilitas \\
\hline 0,764 & 6 & Reliabel \\
\hline
\end{tabular}

Sumber : Hasil Pengolahan data dari kuesioner

Hasil uji reliabilitas didapat dari cronbach's Alpha sebesar 0,764 $\geq \quad 0,6$. Karena ini diatas 0,6 maka dapat disimpulkan bahwa alat ukur dalam penelitian ini reliabel dan dapat dijadikan alat ukur untuk analisis selanjutnya. b) Variabel Volume Penjualan Uji reliabilitas variabel volume penjualan menggunakan SPSS versi 21 for windows yaitu dengan hasil :

Tabel 5

Reliabilitas Statistik

\begin{tabular}{|c|c|c|}
\hline $\begin{array}{c}\text { Cronbach's } \\
\text { Alpha }\end{array}$ & N of Item & Hasil Reliabilitas \\
\hline 0,781 & 6 & Reliabel \\
\hline Sumber : Hasil Pengolahan data dari kuesioner
\end{tabular}

Hasil uji reliabilitas didapat dari cronbach's Alpha sebesar 0,781 $\geq \quad 0,6$. Karena ini diatas 0,6 maka dapat disimpulkan bahwa alat ukur dalam penelitian ini reliabel dan dapat dijadikan alat ukur untuk analisis selanjutnya.
Dari hasil pengolahan data primer dengan menggunakan bantuan program SPSS, nilai tersebut direkapitulasi dalam tabel berikut ini.

Tabel 6.

Rekapitulasi Hasil Uji Reliabilitas

\begin{tabular}{|c|c|c|c|c|}
\hline No & Variabel & $\begin{array}{c}\text { Cronbach's } \\
\text { Alpha Item }\end{array}$ & $\begin{array}{c}\text { Cronbach's } \\
\text { Alpha }\end{array}$ & keterangan \\
\hline 1 & Harga & 0,764 & 0,6 & Reliabel \\
\hline 2 & Vol.penjualan & 0,781 & 0,6 & Reliabel \\
\hline
\end{tabular}

Sumber : data yang diolah dari kuesioner

Dilihat dari hasil pengujian data reliabilitas yang dilakukan dengan bantuan program SPSS versi 21 , Cronbanch's Alpha Item yang lebih besar standar reabilitas yaitu 0,6 maka dapat disimpulkan untuk kedua variabel Cronbach's Alpha Item $\geq$ Nilai Cronbach's Alpha, maka dapat disimpulkan semua item pertanyaan yang ada pada instrumen tersebut dapat dijadikan sebagai alat ukur yang reliabel dalam analisis selanjutnya. 
3) Hasil Pengujian Regresi Linier Sederhana

Analisis regresi sederhana dilakukan untuk mengetahui tingkat pengaruh antara variabel Bebas (variabel Harga) terhadap variabel terikat (variabel vol.penjualan). tabel berikut ini hasil model korelasi sederhana dalam penelitian ini.

Tabel 7

Hasil uji hipotesis t

\begin{tabular}{|c|c|c|c|c|c|}
\hline \multirow[t]{2}{*}{ Model } & \multicolumn{2}{|c|}{$\begin{array}{c}\text { Unstandardized } \\
\text { Coefficients }\end{array}$} & $\begin{array}{c}\text { Standardized } \\
\text { Coefficients }\end{array}$ & \multirow[t]{2}{*}{$t$} & \multirow[t]{2}{*}{ Sig. } \\
\hline & $B$ & $\begin{array}{l}\text { Std. } \\
\text { Error }\end{array}$ & Beta & & \\
\hline $\begin{array}{ll}1 & \begin{array}{l}\text { (Constant) } \\
\text { Harga }\end{array} \\
\end{array}$ & $\begin{array}{r}2,578 \\
, 794\end{array}$ & $\begin{array}{r}3,665 \\
, 175 \\
\end{array}$ & ,703 & $\begin{array}{r}, 703 \\
4,525 \\
\end{array}$ & $\begin{array}{l}, 000 \\
, 027\end{array}$ \\
\hline
\end{tabular}

a. Dependent Variable: PENJUALAN

Sumber: data yang diolah

Berdasarkan tabel 7 diketahui persamaan regresi sederhana sebagai berikut :

$\mathrm{Y}=\mathrm{a}+\mathrm{bX}$

$Y=2,578+0,794 X$

Berdasarkan persamaan ini, konstanta a sebesar 2,578 yang jika variabel bebas (harga) bernilai 0 maka variabel terikat (vol.penjualan) bernilai 2,578 . Sedangkan koefisien regresi $b$ sebesar $=0,794$ berarti jika variabel harga meningkat sebesar 1 satuan maka variabel vol.penjualan meningkat sebesar b yaitu 0,794 satuan.
4) Hasil Pengujian Koefisien Korelasi Sederhana

Korelasi menjelaskan hubungan antara variabel bebas (Variabel Harga) dengan Variabel Terikat (Vol.penjualan). sedangkan koefisien determinasi menjelaskan seberapa besar kontribusi yang diberikan oleh variabel bebas (harga) terhadap variabel Terikat (Vol.penjualan).

Tabel berikut ini menyajikan output yang menjelaskan hasil koefisien korelasi sederhana dan koefisien determinasi dalam penelitian.

Tabel 8

Hasil uji Determinan

\begin{tabular}{|l|r|r|r|r|}
\hline Model & $\mathrm{R}$ & $\begin{array}{c}\mathrm{R} \\
\text { Square }\end{array}$ & $\begin{array}{c}\text { Adjusted R } \\
\text { Square }\end{array}$ & $\begin{array}{c}\text { Std. Error of } \\
\text { the Estimate }\end{array}$ \\
\hline 1 &, $703^{\mathrm{a}}$ &, 494 &, 470 & 2,123 \\
\hline
\end{tabular}

a. Predictors: (Constant), Harga

Sumber : data yang diolah dari kuesioner

Nilai korelasi sederhana berada diantara 0,60 - 0,799, maka dapat disimpulkan bahwa hubungan antara harga dengan volume penjualan pada Mebel Sinar Barokah Tanjung Karangan berada pada kategori kuat.
Dalam analisi koefisien korelasi terdapat koefisien determinasi ( $\mathrm{r} 2)$ yang besarnya adalah kuadrat dari koefisien korelasi (r), koefisien ini disebut koefisien penentu. Dari hasil penggolahan data melalui progam 
SPSS diperoleh nilai determinasi $\mathrm{r} 2=$ 0,494 . Hal ini dapat diartikan bahwa volume penjualan Mebel Sinar Barokah Tanjung Karangan dipengaruhi oleh variabel Harga sebesar 49,4\% sedangkan sisanya $50,6 \%$ dipengaruhi oleh variabel lain yang tidak diteliti pada penelitian ini.

\section{E. PEMBAHASAN}

A. Harga

Harga merupakan salah satu faktor yang mempengaruhi turun naiknya volume penjualan disuatu perusahaan, terutama pada Mebel Sinar Barokah Tanjung Karangan dimana harga adalah jumlah uang yang dibutuhkan untuk mendapatkan sejumlah kombinasi dari produk dan pelayanannya. Selain Harga juga dapat diartikan suatu nilai tukar yang disamakan dengan uang atau barang lain untuk manfaat yang diperoleh dari suatu barang atau jasa bagi seseorang atau kelompok pada waktu tertentu dan tempat tertentu.

Usaha Mebel Sinar Barokah Tanjung Karangan belum menerapkan metode dalam menetapkan harga jual sehingga seakan usaha Mebel Sinar Barokah dalam menentukan harga semata-mata persentase keuntungan yang akan di dapatkan. Penetapan harga jual produk pada usaha Mebel Sinar Barokah Tanjung Karangan mengacu pada jenis dan desain, pihak usaha Mebel Sinar Barokah Tanjung Karangan juga menerapkan tambahan biaya pengiriman yang dimasukan ke harga penjualan suatu produk, sehingga secara tidak langsung konsumen menilai harga yang ditawarkan Mebel Sinar Barokah Tanjung Karangan terlihat tinggi dibandingkan harga yang ditawarkan dari usaha mebel lain.

Selain itu adapun faktor-faktor yang mempengaruhi penetapan harga adalah Keadaan perekonomian sangat mempengaruhi tingkat harga yang berlaku dalam Mebel Sinar Barokah, penawaran dan permintaan sejumlah barang yang dibeli oleh pembeli pada tingkat harga Mebel Sinar Barokah Tanjung Karangan, elastisitas Permintaan sebenarnya sifat permintaan pasar ini tidak hanya mempengaruhi penentuan harganya tetapi juga mempengaruhi volume penjualan yang dapat dijual, persaingan harga jual dapat mempengaruhi volume penjualan dalam hal ini banyaknya penjual yang memproduksi produk yang sama.

Tujuan Penetapan Harga itu sendiri adalah meningkatkan penjualan, mempertahankan dan memperbaiki market share, stabilisasi harga, mencapai target pengembalian modal dan mencapai laba maksimum.

Berdasarkan teori faktor penetapan harga yaitu memperkirakan berapa besarnya harga yang diharapkan dan penjualan dengan harga yang berbeda, reaksi pesaing merupakan salah satu faktor yang mempengaruhi penciptaan harga terutama sekali ancaman persaingan yang potensial, Bauran pemasaran yang lainnya berupa produk, saluran distribusi, dan promosi.

Dari teori yang di jelaskan diatas serta berdasarkan hasil analisa data di lapangan menunjukkan bahwa metode penetapan harga berdasarkan Usaha Mebel Sinar Barokah Tanjung Karangan biaya-biaya yang dikeluarkan termasuk biaya promosi, biaya transfortasi sudah dimasukkan dalam penetapan harga sehingga usaha Mebel Sinar Barokah tidak perlu memberikan tambahan seperti biaya angkut kepada konsumen yang membeli.

Mendukung penelitian yang dilakukan Maqfira Dwi Utami (2013) menunjukkan harga dan biaya promosi ada hubungan yang signifikan dalam 
dalam peningkatan Volume penjualan $\mathrm{R}^{2}=0,993$ artinya ada pengaruh dan hubungan yang signifikan antara harga dan promosi sedangkan dengan teori yang dikemukan oleh 'Machfodz 2005 mengatakan : Penetapan suatu harga dapat dipengaruhi oleh faktor internal yang terdiri dari tujuan perusahaan dalam memasarkan produk, biaya yang dikeluarkan perusahaan untuk memproduksi dan memasarkan produk dan pembiayaan karyawan serta metode yang dipakai perusahaan untuk memasarkan produk dan faktor eksternal yang dapat dilihat dari model pasar yang akan dituju produk, persaingan harga dengan produk lain, serta lingkungan yang akan menjadi sasaran produk tersebut.

\section{B. Volume Penjualan}

Volume penjualan merupakan hasil akhir yang dicapai Mebel Sinar Barokah Tanjung Karangan dari penjualan produk yang dilakukan penjual dihitung berdasarkan target yang diasumsikan dengan realisasi yang dicapai. Volume penjualan tidak memisahkan secara tunai maupun kredit, tetapi dihitung secara keseluruhan dari total yang dicapai. Maka kalau volume penjualan meningkat dan biaya distribusi menurun maka tingkat pencapaian laba Mebel Sinar Barokah Tanjung Karangan meningkat. Tetapi sebaliknya bila volume penjualan menurun maka pencapain laba Mebel Sinar Barokah juga akan mengalami penurunan.

\section{Tabel 9}

Volume Penjualan Mebel Sinar Barokah Tahun 2015-2017

\begin{tabular}{|c|c|c|c|c|}
\hline No & Nama Barang & Tahun 2015 & Tahun 2016 & Tahun 2017 \\
\hline 1 & Lemari 3 Pintu & 253.700 .000 & 326.300 .000 & 312.000 .000 \\
\hline 2 & Lemari 2 pintu & 223.300 .000 & 224.000 .000 & 216.750 .000 \\
\hline 3 & Kursi Tamu & 307.200 .000 & 306.900 .000 & 291.200 .000 \\
\hline 4 & Kursi Makan & 282.000 .000 & 243.750 .000 & 235.000 .000 \\
\hline \multicolumn{2}{|c|}{$\begin{array}{l}\text { Total } \\
\text { Penjualan }\end{array}$} & $\mathbf{1 . 0 6 6 . 2 0 0 . 0 0 0}$ & $\mathbf{1 . 1 0 0 . 9 5 0 . 0 0 0}$ & $\mathbf{1 . 0 5 4 . 9 5 0 . 0 0 0}$ \\
\hline
\end{tabular}

Sumber : Usaha Mebel Sinar Barokah, 2017

Berdasarkan jawaban responden menunjukkan bahwa harga yang di tetapkan Mebel Sinar Barokah sudah sesuai dengan yang di inginkan banyak responden yaitu sebesar 23 orang. Sesuai dengan tanggapan responden terhadap variabel Harga $(X)$ mayoritas jawaban responden menyatakan setuju terhadap harga, kondisi pasar, kualitas produk dan manfaat produk.

\begin{abstract}
Sebagaimana dapat dilihat seberapa besar pengaruh Harga terhadap volume penjualan pada Mebel Sinar Barokah Tanjung Karangan. Koefisien korelasi menjelaskan hubungan antara variabel bebas dan variabel terikat. Koefisien korelasi sebesar 0,703 menunjukkan hubungan yang besar antara variabel harga dan variabel volume penjualan. Koefisien Determinasi menunjukkan Kontribusi variabel bebas terhadap
\end{abstract}


variabel terikat. Koefisien determinasi sebesar 49,4\% menunjukkan kontribusi variabel Harga terhadap Variabel Volume penjualan sebesar 49,4\%, sementara itu sisanya sebesar $50,6 \%(100-49,4 \%)$ dipengaruhi oleh variabel lain yang tidak diteliti dalam penelitian ini.

Analisis regresi sederhana menunjukkan konstanta a sebesar 2,578 artinya harga $(X)$ nilainya adalah 0 , maka volume penjualan (Y) nilainya sebesar 2,578. Sedangkan koefisien regresi variabel Harga (X) sebesar 0,794 artinya jika harga mengalami kenaikan sebesar 1, maka kinerja $(Y)$ akan mengalami peningkatan sebesar 0,794 . Koefisien bernilai positif artinya ada pengaruh positif antara Harga yang dilakukan oleh Mebel Sinar Barokah Tanjung Karangan terhadap Volume Penjualan, semakin sesuai harga yang ditetapkan dengan kualitas antara pesaing maka akan meningkatkan Volume penjualan pada Mebel Sinar Barokah Tanjung karangan.

Uji Hipotesis menunjukkan bahwa hipotesis alternatif diterima. Berdasarkan tabel 5.11 dapat dilihat bahwa nilai thitung untuk variabel Harga (X) adalah sebesar $(4,525) \geq t_{\text {tabel }}$ $(1,721)$, oleh karena itu Ho ditolak dan Ha diterima, maka terdapat pengaruh yang signifikan antara harga terhadap volume penjualan Mebel Sinar Barokah Tanjung Karangan

Memperkuat hasil penelitian yang dilakukakan Endang Tamayani (2015) Hasil penelitian menunjukkan Ada pengaruh yang signifikan positif antara harga terhadap keputusan pembelian dan Ada pengaruh yang signifikan positif antara kualitas produk terhadap keputusan

\section{F. KESIMPULAN DAN SARAN \\ 1) Kesimpulan}

Berdasarkan dari hasil penelitian dan pembahasan pada bab-bab sebelumnya, maka penulis menyimpulkan sebagai berikut :

a) Harga berpengaruh positif terhadap volume penjualan pada Mebel Sinar Barokah Tanjung Karangan. Hal ini dibuktikan dengan nilai thitung adalah sebesar 4,525 lebih besar dari tabel yaitu 1,721 .

b) Besarnya pengaruh harga terhadap volume penjualan pada Mebel Sinar Barokah Tanjung Karangan berdasarkan hasil perhitungan koefisien determinasi adalah sebesar $49,4 \%$ dan sisanya sebesar $50,6 \%$ dipengaruhi oleh faktor lain diluar penelitian ini.

c) Terdapat hubungan yang kuat antara Harga Mebel Sinar Barokah Tanjung Karangan yaitu 0,703 yang berarti jika Variabel Harga meningkat maka variabel volume penjualan mengalami kenaikan, begitupula sebaliknya apabila variabel harga mengalami penurunan maka variabel penjualan mengalami penurunan.

\section{2) Saran}

Berdasarkan kesimpulan diatas, diharapkan dapat menjadi bahan masukkan bagi pihak Mebel Sinar Barokah Tanjung Karangan dimasa yang akan datang, untuk itu penulis menyarankan.

a) Dalam menetapkan Harga Mebel Sinar Barokah Tanjung Karangan sebaiknya di sesuai dengan penetapan harga berdasarkan harga competitor dan penetapan harga berdasarkan permintaan(demand-based pricing).

b) Dalam meningkatkan volume penjualan Mebel Sinar Barokah Tanjung Karangan dapat dilihat 
beberapa indikator seperti kualitas barang, selera konsumen, servis atau pelayanan dan persaingan menurunkan harga jual supaya volume penjualan bisa meningkat dari tahun sebelumnya.

c) Mebel Sinar Barokah Tanjung Karangan tetap meningkatkan kualitas produknya, yang sesuai dengan Mode/Desain yang sedang berlaku saat ini, juga menggunakan strategi penetapan Harga seperti Market Skimming, penetration princing, prestige and economy Princing dan multiple princing

\section{DAFTAR PUSTAKA}

Assauri, Sofjan. 2010. Manajemen Pemasaran. Jakarta: PT. Raja Grafindo Persada

Endang Tamayani, Pengaruh Harga, Kualitas Produk dan Promosi Penjualan terhadap keputusan pembelian pada UD.Wahana Mebel Kediri, Fakultas Ekonomi Universitas Nusantara PGRI Kediri.

Febriawan Adi Sucahyo, Analisis Harga dan Promosi terhadap Volume Penjualan pada Toko Olahraga Sport Smart Fik Uny, fakultas IImu Keolahragaan Universitas Negeri Yogyakarta.

Fitri Ramadhan S (2016), Pengaruh Kualitas Produk, Harga lokasi dan Word Of Mouth Communication Terhadap Minat Beli Konsumen pada CV. Cahaya Jati Sukarame Bandar Lampung, Fakultas Keguruan dan IImu Pendidikan Bandar Lampung.

Hasibuan. Melayu S.P 2008. Manajamen Sumber Daya Manusia. Edisi Cet ke 3. Jakarta: CV.Haji Masagung

Kotler, Philip dan Kevin Lane Keller. 2008. Manajemen Pemasaran. Jakarta: Erlangga

Kotler, Philip, 2005, Manajemen Pemasaran, Penerbit Erlangga Jakarta

Maqfira Dwi Utami, 2013, Analisis Pengaruh harga dan promosi terhadap peningkatan penjualan tiket pada PT. Maniela Tour dan Travel di Makassar, Fakultas Ekonomi Universitas Hasanuddin Makassar.

Sugiyono, 2004, Metode Penelitian Bisnis, Penerbit CV.Alfabeta, Bandung.

Sugiono. 2012. Metode penelitian Bisnis. Bandung. Alfabeta.

Swastha, Basu. 2000. Pengantar Bisnis Modern, Pengantar Ekonomi Perusahaan Modern. Jakarta: Liberty.

Swastha, Basu. 2005. Asas-asas Marketing. Yogyakarta: Liberty 